\title{
METABOLIT SEKUNDER DAN AKTIVITAS FRAKSI ETIL ASETAT KULIT BUAH JENGKOL (PITHECELLOBIUM JIRINGA (JACK) PRAIN.) TERHADAP BAKTERI PSEUDOMONAS AERUGINOSA DAN BACILLUS SUBTILIS
}

\author{
Adam M. Ramadhan*, Ririn Pangaribuan, Arsyik Ibrahim \\ Laboratorium Penelitian dan Pengembangan FARMAKA TROPIS, Fakultas Farmasi, \\ Universitas Mulawarman, Samarinda, Kalimantan Timur \\ *email: $\underline{\text { adam@farmasi.unmul.ac.id }}$
}

\begin{abstract}
This research aims to determine the identification of secondary metabolites and antibacterial activity of ethyl acetate fraction of Jengkol fruit peel (Pithecellobium jiringa (Jack) Prain.) against the bacteria Pseudomonas aeruginosa and Bacillus subtilis. Identification of secondary metabolites is done by testing be qualitative. Antibacterial activity assays performed by agar diffusion method with a test concentration are 0,5\%, $1 \%, 5 \%, 10 \%$ and $15 \%$. The results of identification of secondary metabolites are flavanoid, fenolic and tannin. Data has been analyzed with measuring the diameter of the kill zone of ethyl acetat fraction of Jengkol fruit peel against bacterial growth. The result of research showed that ethyl acetat fraction of Jengkol fruit peel produce radical zone. The effective concentration of ethyl acetate of Jengkol fruit peel was 15\% against the bacteria Pseudomonas aeruginosa and Bacillus subtilis.
\end{abstract}

Keywords: Secondary metabolites, antibacterial activity, Pithecellobium jiringa (Jack) Prain.

\begin{abstract}
ABSTRAK
Penelitian ini bertujuan untuk mengidentifikasi golongan senyawa metabolit sekunder dan mengetahui aktivitas antibakteri fraksi etil asetat kulit buah jengkol (Pithecellobium jiringa (Jack) Prain.) terhadap bakteri Pseudomonas aeruginosa dan Bacillus subtilis. Identifikasi metabolit sekunder dilakukan dengan uji kualitatif. Pengujian aktivitas antibakteri dilakukan dengan metode difusi agar dengan konsentrasi uji $0,5 \%, 1 \%, 5 \%, 10 \%$ dan $15 \%$. Hasil identifikasi golongan senyawa metabolit sekunder terdapat senyawa flavanoid, fenolik dan tanin. Data hasil penelitian aktivitas antibakteri dianalisis dengan mengukur diameter zona bunuh fraksi etil asetat kulit buah jengkol terhadap pertumbuhan bakteri. Hasil penelitian menunjukkan bahwa fraksi etil asetat kulit buah jengkol memiliki aktivitas dalam membunuh pertumbuhan baktri uji. Konsentrasi efektif fraksi etil asetat kulit buah jengkol untuk membunuh bakteri Pseudomonas aeruginosa dan Bacillus subtilis yaitu pada konsentrasi $15 \%$.
\end{abstract}

Kata kunci: Metabolit sekunder, aktivitas antibakteri, Pithecellobium jiringa (Jack) Prain.

\section{PENDAHULUAN}

Infeksi adalah gangguan kesehatan yang dialami manusia akibat adanya bakteri yang masuk dalam tubuh. Banyaknya infeksi yang sering terjadi pada masyarakat maka banyak pula pengembangan obat antibakteri untuk mengobatinya. Namun, banyaknya efek samping yang ditimbulkan oleh obat antibakteri maka banyak masyarakat 
beralih pengobatan konvensional menuju ke pengobatan herbal. Salah satu agen antibakteri yang masih jarang atau tidak diketahui masyarakat adalah kulit buah jengkol.

Pseudomonas aeruginosa adalah bakteri gram negatif bersifat patogen oportunistik, yaitu memanfaatkan kerusakan pada mekanisme pertahanan inang untuk memulai suatu infeksi, dan menyebabkan infeksi pada manusia dengan ketahanan tubuh yang menurun [1].

Bacillus subtilis adalah bakteri gram positif bersifat aerob, tumbuh pada agar darah membentuk zona hemolisis beta yang lebih lebar [2].

Efek samping yang sering ditimbulkan antibiotik yaitu terjadinya resistensi bakteri sehingga ini merupakan peluang besar dalam pemanfaatan kekayaan keanekaragaman hayati untuk mendapatkan senyawa bioaktif yang berfugsi sebagai antibakteri.

Penelitian ini bertujuan untuk mengidentifikasi kandungan metabolit sekunder dan mengetahui aktivitas antibakteri dari fraksi etil asetat kulit buah jengkol (Pithecellobium jiringa (Jack) Prain.) terhadap bakteri Pseudomonas aeruginosa dan Bacillus subtilis.

\section{METODE PENELITIAN}

\section{Bahan}

Bahan yang diteliti adalah simplisia kulit buah jengkol. Pelarut yang digunakan untuk ekstraksi dan fraksinasi adalah metanol, n-heksana dan etil asetat. Bakteri uji yang digunakan adalah Pseudomonas aeruginosa dan Bacillus subtilis. Medium yang digunakan adalah Nutrient Agar (NA). $\mathrm{NaCl}$ 0,9\% sebagai pensuspensi bakteri. Bahan kimia yang digunakan adalah asam klorida, kalium heksasianoferat (III), besi (III) klorida, asam asetat anhidrat, kloroform, asam sulfat, pereaksi Dragendorff dan pereaksi Mayer.

\section{Peralatan}

Peralatan yang digunakan dalam penelitian ini antara lain bejana maserasi, rotary evaporator, waterbath, timbangan analitik, cawan porselin, labu ukur, corong pisah, tabung reaksi, autoklaf, oven, inkubator, cawan petri, erlenmeyer, spoit injeksi dan alat penunjang lainnya.

\section{Pengumpulan dan Penyiapan Sampel}

Kulit buah jengkol diperoleh dari Kota Balikpapan, Kalimantan Timur. Kulit buah jengkol segar dikumpulkan kemudian disortasi basah. Setelah itu, kulit buah jengkol dicuci dan dikeringkan dengan cara diangin-anginkan didalam ruangan yang terlindung dari sinar matahari secara langsung. Selanjutnya kulit buah jengkol kering disortasi kering dan dipotong kecil-kecil menjadi serbuk simplisia.

\section{Ekstraksi dan Fraksinasi}

Serbuk simplisia dimasukkan kedalam bejana maserasi dan dimaserasi menggunakan pelarut metanol. Proses ekstraksi dengan metode maserasi berlangsung selama kurang lebih 5 (lima) hari. Maserat (hasil maserasi) disaring menggunakan kertas saring dan ditampung kedalam wadah. Maserat kemudian dipekatkan menggunakan rotary evaporator dan dilanjutkan dengan penguapan di atas waterbath hingga diperoleh ekstrak metanol kental.

Proses fraksinasi dilakukan secara bertingkat dengan metode fraksinasi caircair. Fraksinasi akan dibuat fraksi $n$ heksana, etil asetat dan n-butanol. Ekstrak metanol ditimbang 10 gram kemudian dilarutkan air suling sebanyak $100 \mathrm{~mL}$. Selanjutnya dimasukkan kedalam corong pisah, ditambahkan 100 $\mathrm{mL}$ pelarut n-heksana dan dilakukan pengojogkan. Setelah itu didiamkan sehingga terbentuk 2 (dua) lapisan. Lapisan bawah diambil untuk dilanjutkan fraksinasi selanjutnya. Dalam setiap pelarut organik dilakukan pengulangan hingga lapisan atas terlihat bening. 
Lapisan atas hasil fraksinasi dikeringkan atau diuapkan sehingga diperoleh ekstrak kering atau ekstrak kental. Fraksi etil asetat yang diperoleh diuji fitokimia dan aktivitas antibakterinya.

\section{Uji Metabolit Sekunder}

Identifikasi metabolit sekunder dilakukan pada fraksi etil asetat. Uji identifikasi metabolit sekunder meliputi uji kandungan alkaloid, flavanoid, senyawa fenol, tanin, saponin, steroid dan triterpenoid. Pengujian dilakukan dengan menggunakan reagen yang berfungsi pada masing-masing kandungan senyawa kimia yang sesuai. Uji alkaloid menggunakan pereaksi Dragendorff dan pereaksi Mayer. Uji flavanoid menggunakan logam magnesium dan asam klorida. Uji senyawa fenol menggunakan larutan kalium heksasianoferat (III) dan besi (III) klorida. Uji tanin menggunakan larutan besi (III) klorida. Uji saponin menggunakan aquades dan asam klorida. Uji steroid dan triterpenoid menggunakan asam asetat anhidrat, kloroform dan asam sulfat.

\section{Pengujian Antibakteri}

Pengujian aktivitas antibakteri fraksi etil asetat kulit buah jengkol dilakukan dengan metode difusi agar dengan menggunakan medium NA. Suspensi bakteri dari pengenceran 1:40 sebanyak $0,02 \mathrm{ml}$ dicampur dengan $10 \mathrm{ml}$ medium NA di dalam botol pengencer, digojog agar homogen kemudian dituang ke dalam cawan petri. Ditunggu hingga medium padat. Paperdisc dicelupkan di dalam larutan uji lalu diletakkan di atas permukaan medium NA yang telah padat, dan diinkubasi pada suhu $37{ }^{\circ} \mathrm{C}$ selama 24 jam. Kontrol negatif menggunakan paperdisc yang telah dicelupkan di dalam air suling.

\section{HASIL DAN PEMBAHASAN}

\section{a. Metabolit Sekunder}

Metabolit sekunder adalah senyawa metabolit yang tidak essensial bagi pertumbuhan organisme. Fungsi metabolit sekunder adalah untuk mempertahankan diri dari kondisi lingkungan yang kurang menguntungkan.

Hasil identifikasi metabolit sekunder fraksi etil asetat kulit buah jengkol maka diperoleh hasil positif yaitu golongan senyawa flavanoid, fenolik, dan tanin. Hasil uji metabolit sekunder dapat dilihat pada Tabel 1.

Tabel 1. Metabolit sekunder fraksi etil asetat kulit buah jengkol

\begin{tabular}{cccccccc}
\hline Sampel & \multicolumn{6}{c}{ Metabolit Sekunder } \\
\cline { 2 - 7 } Uji & Alkaloid & Flavanoid & Fenolik & Tanin & Saponin & Steroid & Triterpenoid \\
\hline Fraksi & - & + & + & + & - & - & - \\
Etil Asetat & - & + & & & - & & - \\
\hline
\end{tabular}

Keterangan:

$(+)=$ terdeteksi metabolit sekunder

(-) = tidak terdeteksi metabolit sekunder

Hasil identifikasi golongan metabolit sekunder terhadap fraksi etil asetat kulit buah jengkol seperti terlihat pada Tabel 1. Golongan senyawa alkaloid tidak terindentifikasi yang ditandai dengan tidak terbentuknya endapan putih setelah ditambahkan pereaksi Mayer dan tidak terbentuknya endapan jingga setelah ditambahkan pereaksi Dragendorff. Selain senyawa alkaloid, senyawa steroid dan tritepenoid tidak teridentifikasi dengan tidak terbentuknya warna benar dan warna biru setlah ditambahkan pereaksi uji. Demikian 
halnya dengan saponin yang tidak teridentifikasi dengan tidak terbentuknya busa yang stabil [3].

Pada uji identifikasi kandungan metabolit sekunder, senyawa fenolik menunjukkan hasil positif yang ditandai terbentuknya warna biru kehitaman setelah ditambahkan pereaksi uji. Selain itu, senyawa flavanoid menunjukkan hasil positif yang ditandai terbentuknya warna merah setelah ditambahkan pereaksi uji. Senyawa tanin juga menunjukka hasil positif yang ditandai terbentuknya warna biru kehitaman setelah ditambahkan pereaksi uji [3].

\section{b. Aktivitas Antibakteri Kulit Buah Jengkol}

Hasil uji aktivitas antibakteri menunjukkan bahwa fraksi etil asetat kulit buah jengkol memiliki aktivitas antibakteri terhadap bakteri Pseudomonas aeruginosa dan Bacillus subtilis yang ditandai adanya zona bunuh di sekitar paperdisc. Kontrol negatif yaitu air suling tidak menghasilkan zona bunuh di sekitar paperdisc sehingga dapat dikatakan bahwa air suling tidak berpengaruh terhadap aktivitas antibakteri, hal ini membuktikan bahwa aktivitas antibakteri merupakan aktivitas dari fraksi etil asetat kulit buah jengkol.

Pengujian aktivitas antibakteri fraksi etil asetat kulit buah jengkol terhadap bakteri Pseudomonas aeruginosa dan Bacillus subtilis dilakukan dengan 5 (lima) variasi konsentrasi yaitu $0,5 \%, 1 \%, 5 \%, 10 \%$ dan $15 \%$. Hasil pengujian dari aktivitas antibakteri fraksi etil asetat kulit buah jengkol dapat dilihat pada Gambar 1.
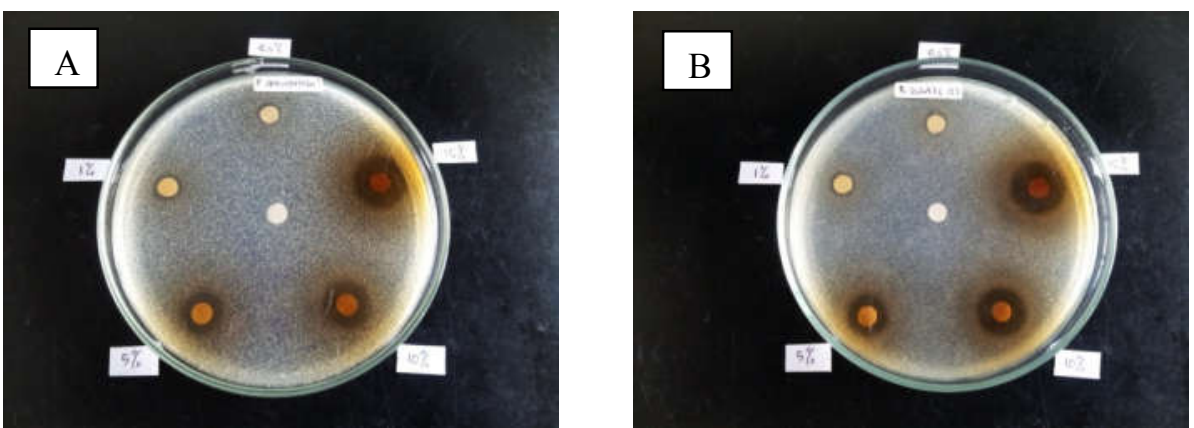

Gambar 1. Uji antibakteri fraksi etil asetat kulit buah jengkol terhadap bakteri (A) Pseudomonas aeruginosa dan (B) Bacillus subtilis

Zona bunuh yang terbentuk disekitar paperdisc yang diukur dengan menggunakan mikrometer skrup dapat dikategorikan sesuai kekuatan aktivitas antibakteri fraksi etil asetat kulit buah jengkol. Kriteria suatu antibakteri dikatakan mempunyai aktivitas terhadap bakteri jika mempunyai ketentuan kekuatan sebagai berikut, luas daerah hambatan $20 \mathrm{~mm}$ atau lebih masuk kategori sangat kuat, daerah hambatan antara 10-20 mm masuk kategori kuat, daerah hambatan antara 5-10 mm masuk kategori sedang dan daerah hambatan 5 $\mathrm{mm}$ atau kurang masuk dalam kategori lemah [4]. Data hasil pengukuran zona bunuh fraksi etil asetat kulit buah jengkol dapat dilihat pada Tabel 2 . 
Tabel 2. Data aktivitas antibakteri fraksi etil asetat

\begin{tabular}{cccc}
\hline \multirow{2}{*}{ Sampel Uji } & Konsentrasi & \multicolumn{2}{c}{ Rerata Diameter Zona Bunuh (mm) } \\
\cline { 3 - 4 } & $(\%)$ & Pseudomonas aeruginosa & Bacillus subtilis \\
\hline Fraksi & 0,5 & 1,61 & 1,09 \\
etil asetat & 1 & 1,83 & 1,34 \\
& 5 & 4,47 & 4,54 \\
& 10 & 6,57 & 7,62 \\
Kontrol Negatif & 15 & 9,31 & 8,81 \\
(Air suling) & 0 & 0 & 0 \\
\hline
\end{tabular}

Tabel 2 menunjukkan bahwa daya aktivitas antibakteri fraksi etil asetat kulit buah jengkol terhadap bakteri Pseudomonas aeruginosa dan Bacillus subtilis pada konsentrasi $0,5 \%, 1 \%$ dan $5 \%$ termasuk lemah sedangkan konsentrasi $10 \%$ dan $15 \%$ termasuk kategori sedang.

Gambar 2. merupakan kurva grafik perbandingan zona bunuh fraksi etil asetat kulit buah jengkol terhadap bakteri Pseudomonas aeruginosa dan Bacillus subtilis.

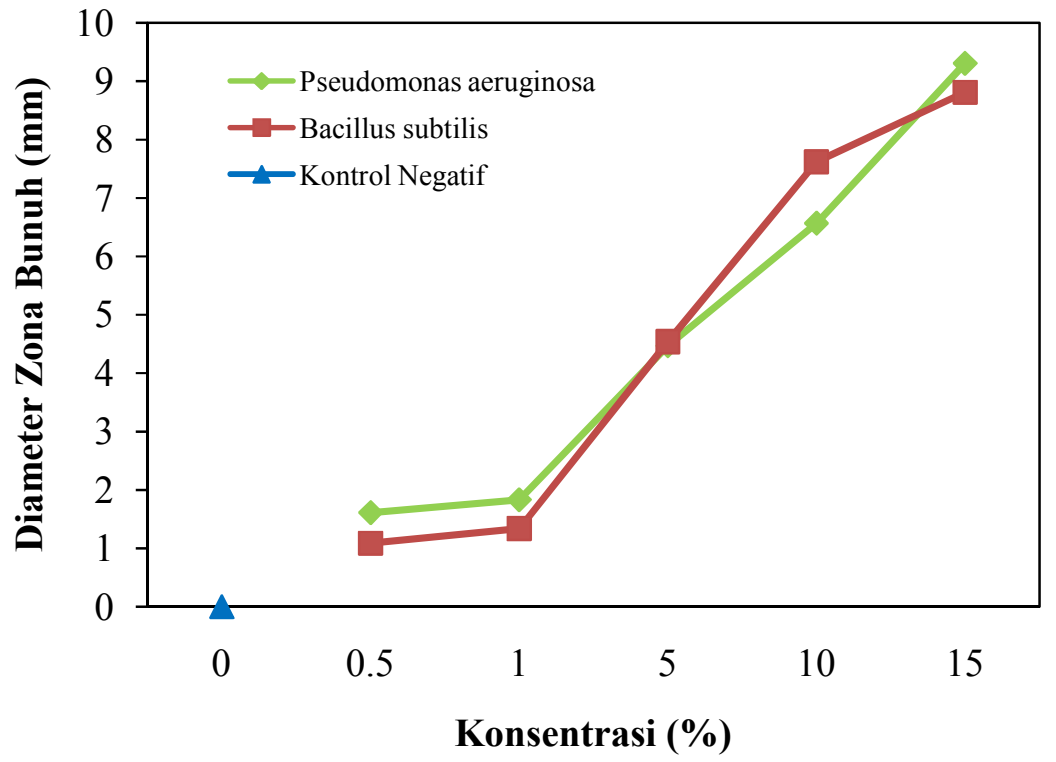

Gambar 2. Pengaruh konsentrasi fraksi etil asetat kulit buah jengkol terhadap diameter zona bunuh bakteri Pseudomonas aeruginosa dan Bacillus subtilis.

Gambar 2. menunjukkan adanya aktivitas antibakteri dari masing-masing konsentrasi fraksi etil asetat kulit buah jengkol. Hal ini ditandai dengan adanya diameter zona bunuh yang diperoleh disetiap konsentrasi fraksi etil asetat. Dapat dilihat dari grafik bahwa titik puncak kenaikan aktivitas daya bunuh fraksi etil asetat terhadap bakteri Pseudomonas aeruginosa dan Bacillus subtilis yaitu pada konsentrasi $15 \%$. Dilihat dari hasil diameter zona bunuh yang dihasil dari fraksi etil asetat, yaitu meningkatnya konsentrasi uji fraksi etil asetat dapat meningkatkan daya bunuh bakteri. Namun, apabila konsentrasi uji 
dari fraksi etil asetat kulit buah jengkol terus ditingkatkan maka dapat terjadi pula penurunan daya bunuh bakteri. Hal ini dimungkinkan karena peningkatan konsentrasi menyebabkan viskositas dari fraksi etil asetat semakin meningkat, sehingga dapat mempengaruhi kecepatan difusi fraksi tersebut dalam media agar.

Konsentrasi efektif fraksi etil asetat kulit buah jengkol adalah konsentrasi terendah fraksi yang memberikan kemampuan terbaik dalam membunuh bakteri uji. Konsentrasi efektif ditandai dengan luas diameter zona bunuh yang terbesar dari aktivitas antibakteri fraksi kulit buah jengkol. Data aktivitas antibakteri dianalisi menggunakan Anava satu arah dan uji lanjutan Beda Nyata Jujur Duncan (BNJD). Hasil konsentrasi efektif fraksi etil asetat kulit buah jengkol terhadap bakteri Pseudomonas aeruginosa dan Bacillus subtilis dapat dilihat pada Tabel 3.

Tabel 3. Konsentrasi efektif fraksi etil asetat

\begin{tabular}{ccc}
\hline Bakteri Uji & Konsentrasi Efektif (\%) & Diameter Zona Bunuh (mm) \\
\hline Pseudomonas aeruginosa & 15 & 9,31 \\
Bacillus subtilis & 15 & 8,81 \\
\hline
\end{tabular}

Tabel 3. menunjukkan bahwa konsentrasi efektif fraksi etil asetat kulit buah jengkol dapat membunuh bakteri Pseudomonas aeruginosa dan Bacillus subtilis adalah konsentrasi $15 \%$ dengan diameter zona bunuh terbesar dibandingkan dengan konsentrasikonsentrasi uji lainnya yaitu $9,31 \mathrm{~mm}$ dan $8,81 \mathrm{~mm}$.

Faktor konsentrasi, jenis bahan antibakteri juga menentukan kemampuan menghambat pertumbuhan bakteri [5]. Aktivitas antibakteri fraksi etil asetat kulit buah jengkol diduga karena adanya kandungan senyawa-senyawa berkhasiat yaitu flavanoid, fenolik dan tanin.

\section{KESIMPULAN}

Berdasarkan penelitian yang telah dilakukan, dapat diperoleh kesimpulan sebagai berikut:

1. Kandungan metabolit sekunder dari fraksi etil asetat kulit buah jengkol (Pithecellobium jiringa (Jack) Prain.) adalah senyawa golongan flavanoid, fenolik dan tanin.

2. Fraksi etil asetat kulit buah jengkol (Pithecellobium jiringa (Jack) Prain.) memiliki aktivitas antibakteri terhadap bakteri Pseudomonas aeruginosa dan Bacillus subtilis.

3. Konsentrasi efektif fraksi etil asetat kulit buah jengkol (Pithecellobium jiringa (Jack) Prain.) untuk bakteri Pseudomonas aeruginosa dan Bacillus subtilis yaitu $15 \%$.

\section{DAFTAR PUSTAKA}

1. Natalia, L. 2008. Pesudomonas aeruiginosa, Penyebab Infeksi Nosokomial. Available form: mikroba.files.wordpress.com.

2. Naibaho, P. 2011. Daphnia sp (Klasifikasi, Morfologi, Reproduksi), Bacillus subtilis, Bakteri Nitrifikasi, Sistem Kultur Zooplankton, Parameter Kualitas Air. Available form:pobersonnaibaho.wordpress.com

3. Harborne, J. B. 2006. Metode Fitokimia. Penerbit ITB: Bandung

4. Davis, W. W and Stout, T. R. 1971. Disc Plate Methods of Microbiological Antibiotic Assay. Microbiology. 22(4): 659-665.

5. Ajizah, A. 2004. Sensitivitas Salmonella typhimurrium Terhadap Ekstrak Daun Psidium guajava L. Bioscientiae. 1(1) : 31-38. 